\title{
Identification and characterization of critical sites for small pelagic fish in the coastal marine area of Senegal, West Africa
}

\author{
Ndour Ismaïla (Corresponding Author) \\ Institut Sénégalais de Recherches Agricoles (ISRA), Centre de Recherches \\ Océanographiques de Dakar-Thiaroye (CRODT), BP 2241, Dakar, Sénégal. Tel: +221 77608 \\ 1344 E-mail: ndismaila@gmail.com
}

\begin{abstract}
Baldé Assiatou
Université Cheikh Anta Diop de Dakar (UCAD), Institut Universitaire de Pêche et d'Aquaculture (IUPA), B.P.5085, Dakar-Fann, Sénégal. Tel: +221 784627885 E-mail: assitoubalda@gmail.com
\end{abstract}

\section{Thiam Ndiaga}

Institut Sénégalais de Recherches Agricoles (ISRA), Centre de Recherches Océanographiques de Dakar-Thiaroye (CRODT), BP 2241, Dakar, Sénégal. Tel: +221 70607 2835 E-mail: ndiagathiam@hotmail.com

\section{Thiaw Modou}

Institut Sénégalais de Recherches Agricoles (ISRA), Centre de Recherches Océanographiques de Dakar-Thiaroye (CRODT), BP 2241, Dakar, Sénégal. Tel: +221 77445 2391 E-mail: modouth@ hotmail.fr

Faye Saliou

Institut Sénégalais de Recherches Agricoles (ISRA), Centre de Recherches Océanographiques de Dakar-Thiaroye (CRODT), BP 2241, Dakar, Sénégal. Tel: +221 77303 4129 E-mail: fayebayzal100@yahoo.fr

Fall Massal

Institut Sénégalais de Recherches Agricoles (ISRA), Centre de Recherches 
Océanographiques de Dakar-Thiaroye (CRODT), BP 2241, Dakar, Sénégal. Tel: +221 77648

3936 E-mail: massal.fall@gmail.com

\author{
Diop Mika \\ Commission Sous Régionale des Pêches (CSRP), BP. 25485, Dakar, Sénégal. Tel: +221 \\ $776448218 \quad$ E-mail: mika.diop@spcsrp.org
}

Received: July 23, 2019 Accepted: August 25, 2019

doi:10.5296/jbls.v11i1.15131 URL: https://doi.org/10.5296/jbls.v11i1.15131

\begin{abstract}
Better management of coastal marine resources generally requires good knowledge of habitats and resources. This need led to the performance of an identification and bioecological characterization study of critical sites for small pelagics in the Senegalese coastal marine zone. Biological and ecological data were collected using beach seines (12 to $28 \mathrm{~mm}$ mesh) and surface drifting gillnets (28 to $36 \mathrm{~mm}$ mesh) at sites identified by fishermen on the basis of surveys. The results of the study highlight the bioecological characteristics of these sites: (i) the Port-Baie Hann site - a nursery and spawning site with a high diversity for the target species; it is under marine pollution threat; (ii) the Mbodiène-Ngazobil site, with high diversity for target species and the Kafountine-Cap site are nursery and spawning sites under high fishing pressure, (iii) the Diakhanor-Sangomar site - a spawning site under the potential threat of exploration of offshore Sangomar oil in addition to the high fishing pressure. This work is a first flagship contribution to a process that should lead to the development and control of new tools for the effective and sustainable management of small pelagics at national and regional scales.
\end{abstract}

Keywords: critical sites, small pelagic fish, fisheries management, Senegal, West Africa

\title{
1. Introduction
}

In Senegal, small pelagic fishery provide the basis for a multitude of activities (fishing, fish processing and selling) and jobs. It supplies of cheap protein. So, $75 \%$ of the proteins consumed come from fishing, especially small pelagics (Dème et al., 2012). Sardinella catches represent $70 \%$ of the total landings of artisanal fisheries in Senegal (Thiaw et al., 2017). The Sardinella fishery contributes mainly to the supply of local and regional markets (Dème et al., 2012; Ba et al., 2017). It employs more than 25\% of artisanal fishermen (16,000 fishermen) and provides about $70 \%$ of Senegal's fish consumption (Ba et al., 2017). In addition to these socio-economic benefits (Dème, 2012), small coastal pelagic species (PPC) are also of ecological interest because of their position in the trophic food web (Cury et al., 2000). 


\section{Macrothink

Despite these socio-economic and ecological benefits, these resources are under high fishing pressure due to increased effort and fishing capacity. In addition, the installation of fishmeal factories since 2010 along the coastline, closest to the landing sites, increases the fishing pressure on small pelagics (Mbaye, 2018). The development of illegal fish processing sites, mainly Sardinella and ethmalose, also encourages the exploitation of juveniles of small pelagics in Senegal. In such a context, it is necessary to strengthen the management of the small pelagic fishery by setting up appropriate management and conservation tools for the stocks and their habitats.

This is the objective of this study, which aims to contribute to improving the management of small pelagics, mainly sardinella (Sardinella maderensis and $S$. aurita), ethmalose (Ethmalosa fimbriata), yellow horse mackerel (Caranx rhonchus), black horse mackerel (Trachurus trecae), mackerel (Scomber colias), anchovy (Engraulis encrasicolus) and sardine (Sardina pilchardus), through the bio-ecological characterization of critical sites for small pelagics in Senegalese waters.

The concept of "critical site" is defined by the SRFC-RAMPAO Working Group of October 2018 as being: "a site of bioecological importance for small pelagics with a high socio-economic or cultural interest, exposed to threats likely to disturb environment and to compromise its ecosystem goods and services ". By this definition, the characterization of critical sites for small pelagics is of great interest for better management of this resource for the benefit of local communities.

\section{Material and Methods}

\subsection{Study Area}

The Senegalese coast is divided into three large zones: the Grande Côte which extends from St. Louis $\left(16^{\circ} 04^{\prime} \mathrm{N}\right)$ to the Cape Verde Peninsula $\left(14^{\circ} 36^{\prime} \mathrm{N}\right)$, the Petite Côte that goes from Dakar $\left(14^{\circ} 36^{\prime} \mathrm{N}\right)$ to the North Sea border of The Gambia $\left(13^{\circ} 36^{\prime} \mathrm{N}\right)$ and the Casamance between the latitudes $13^{\circ} 04$ 'and 12 20'N (Roy, 1989; Dème-Gning et al., 1990). Identified by previous work as the main nursery and spawning grounds for small pelagics, Cape Verde, Petite Côte and Casamance were chosen for this study (Figure 1). Sites previously identified by local fishermen and located in these coastal areas were all sampled. These were the sites of Soumbédioune-Ouakam, Port-Baie de Hann, Yenne-Bargny, (Cape Verde), Cape de Naze, Mbodiène-Ngazobil, Diakhanor-Sangomar (Petite Côte), and Kafountine -Cap (Casamance) (Figure 1). 


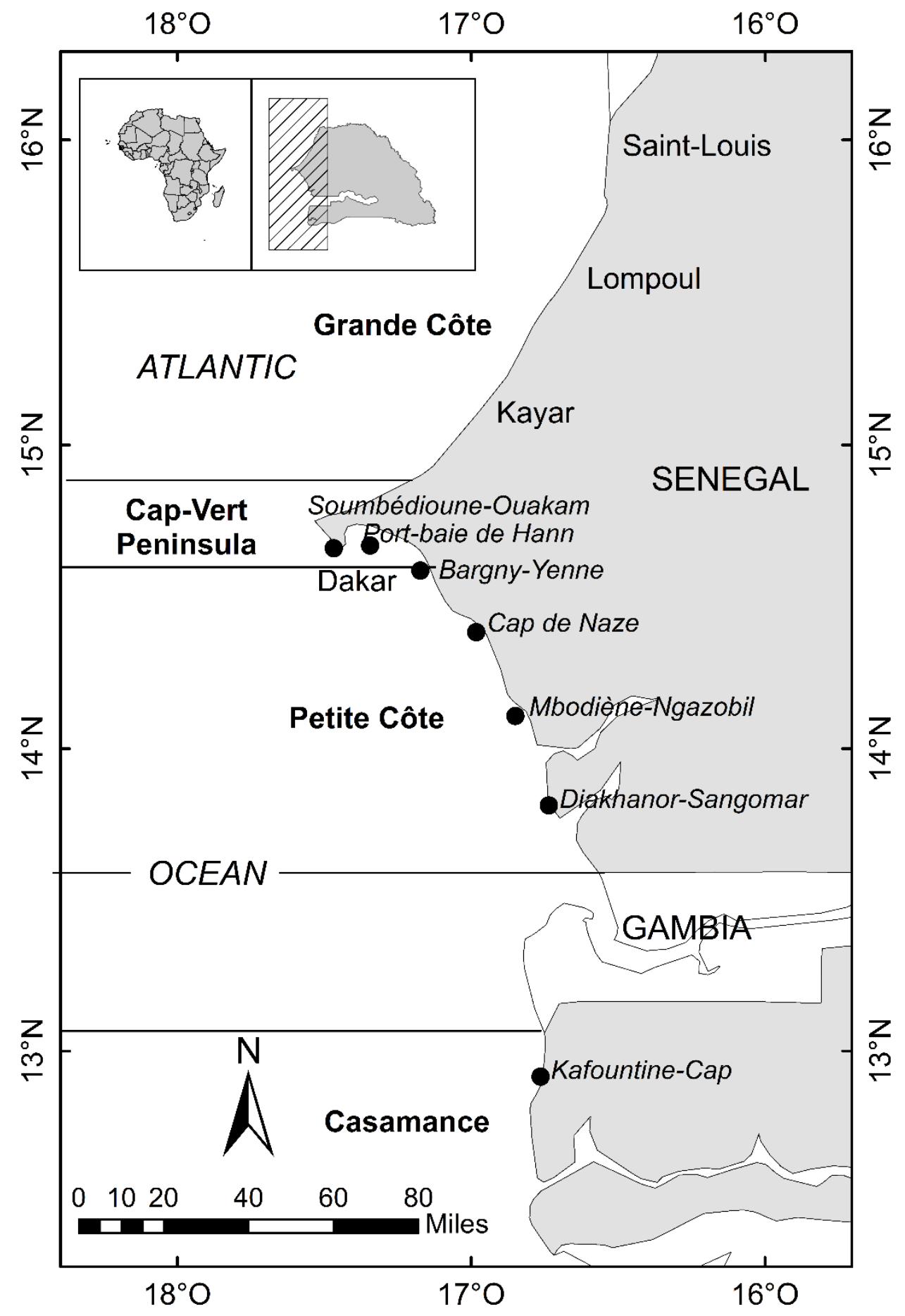

Figure. 1. Location of critical sites for small pelagics sampled along the coastal marine area of Senegal

\subsection{Surveys}

In order to identify the critical sites of small pelagics (nursery and spawning grounds), surveys were carried out among 459 people composed mainly of fishermen. According to the socio-demographic profiles of the people interviewed, the Lebou (52\%), guet-ndarien (17\%) and niominka (16\%) communities were the most represented. Considering residency status, 
indigenous were the majority $(92 \%)$ in our surveys. The majority of the fishermen interviewed (30\%) had fishing experience range of 20-30 years. In terms of fishing specialty, fishermen using mixed gear (targeting pelagic and demersal species) and those specializing in pelagic species were the most represented in our surveys, $52 \%$ and $39 \%$ respectively.

\subsection{Experimental Fishing}

Experimental fishings were conducted using a beach seine (SP) of 12 to $28 \mathrm{~mm}$ mesh and a surface drift gillnet (FMDS) of 28 to $36 \mathrm{~mm}$ mesh. The lengths of fishing gear ranged from 100 to $200 \mathrm{~m}$. The choice of these fishing gear was explained by their complementarity for good longitudinal, bathymetric and species size coverage. The FMDS targets relatively large pelagic and semi-pelagic species, while SP catches the same species in smaller sizes. In addition, the fishing areas of the beach seine were more coastal than those of the FMDS. In each site, two fishing trips were made with each gear, to ensure the representativeness of the sample in terms of spatial coverage and number of individuals captured.

For the FMDS, the sampling was done at night: laying the net was done the day before at 7 $\mathrm{pm}$ and it was removed at 7 am the next day. As for the beach seine, the samplings were performed during the day between 7 am and $1 \mathrm{pm}$. After each fishing trip, fish were sorted by species. The individuals were measured, sexed, and sexual maturity stages determined according to the Albaret \& Legendre (1985) scale. In addition, total catches as well as catches by species were noted.

\subsection{Data Processing}

Characterization of critical sites was performed on the basis of bio-ecological indicators such as size spectrum, sexual maturity stages and condition factor.

The analysis of the size spectrum makes it possible to verify the presence of juveniles or adults of the targeted species in the site. Total length (LT) was measured in fish to the nearest centimeter. Size classes of $0.5 \mathrm{~cm}$ were established.

The stage of sexual maturity informs about the occurrence of immature (stage $<3$ ) or mature (stage $\geq 3$ ) fish, especially spawners in the laying phase (stages 4 and 5), according to the Albaret \& Legendre (1985) scale.

The Fulton's condition factor K (Ricker, 1975) makes it possible to analyze the relationship between the species and its environment. Fish that live in unfavorable conditions generally have low weights relative to their length, i.e a low $\mathrm{K}$, and vice versa. The $\mathrm{K}$ factor is a parameter that provides information on the physical shape of the fish. It was calculated according to the standard formula below:

$$
K=\frac{W}{\mathrm{TL}^{3}} * 10^{5}
$$

Where $\mathrm{W}$ is the total weight of the fresh fish $(\mathrm{g})$ and TL is the total length of the fish $(\mathrm{cm})$.

The sizes of first sexual maturity $\left(\mathrm{L}_{50}\right)$ of the target species obtained in previous work carried 


\section{Macrothink}

out especially in Senegal or in general in the sub-region were used to separate the immature individuals from those which were mature. Otherwise, the $\mathrm{L}_{50}$ of the targeted species were collected from Fishbase. The relative abundance of the species was calculated from the percentage of the number of individuals.

\subsection{Statistical Analysis}

Multivariate analysis techniques such as factorial and automatic classification analysis methods were applied to resume the complex structure of data used in this study. The Hierarchical Classification Analysis (HCA) was used to group sites according to their affinity or similarity in terms of abundance and of diversity. Factorial Correspondence Analysis (FCA) was also carried out using fish abundance to investigate the pattern of small pelagic assemblage between sites. The dendrograms were performed using the Euclidean distance and the Ward minimum variance clustering method. Statistical analyses were carried out using R software and ade4 package.

\section{Results}

\subsection{Identification of Critical Sites}

The results of surveys on critical sites for small pelagic fish showed, by zone, the main nursery and spawning sites (Figures 2A, B, C). In the Cap-Vert area, the sites of Soumbédioune-Ouakam (37.7\% and 27.2\%), Port-Baie de Hann (20.2\% and 20.7\%) and Yenne-Bargny (21.9\% and $17.9 \%$ ) were identified, by fishermen, as the most important critical sites (Figure 2A). The sites of Diakhanor-Sangomar (34.1\% and $39.6 \%$ ) and Mbodiène-Ngazobil (28.8\% and 25.4\%) were considered by the fishermen as being the main nursery and spawning sites in the Petite Côte area (Figure 2B). In the Casamance zone (Figure 2C), the main critical site identified by fishermen was Kafountine-Cap (70\% and $69.8 \%)$. 

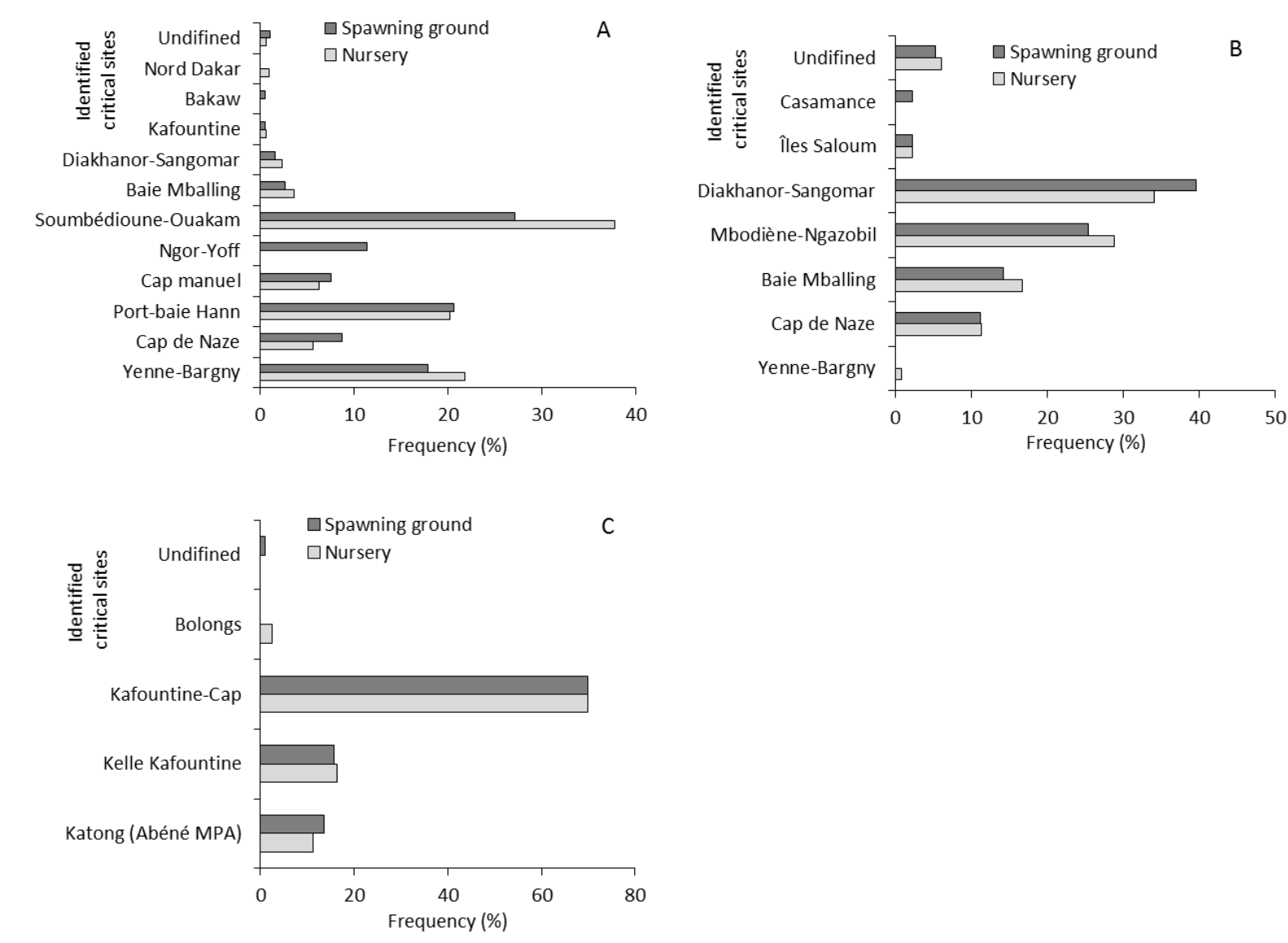

Figure 2. Importance (in \%) of critical sites identified by fishermen along the Senegalese marine coastal area through a survey realized in different sampling sites: A) Cape Verde; B)

Petite Côte and C) Casamance

\subsection{Bio-Ecological Characterization of the Sites}

\subsubsection{Fish Composition and Relative Abundance}

A high diversity of species was noted in the sites of Port-Baie de Hann (8 species), Mbodiène-Ngazobil and Diakhanor-Sangomar (5 species each). Although the number of species was lower, the latter two sites had the highest relative abundances with respectively $51.6 \%$ and $26.2 \%$ of the catches. The species C. rhonchus (38.6\%), E. fimbriata (27.9\%), S. maderensis $(17.4 \%)$ and S. aurita $(8.5 \%)$ were the most abundant in all sites (Table 1). However, the highest catches were recorded at the sites of Diakhanor-Sangomar (54.2\%) and Port-Baie de Hann (33.1\%) (Table 2). 
Table 1. Composition and relative abundance $(\%)$ of target species by site along the coastal marine zone of Senegal

\begin{tabular}{|c|c|c|c|c|c|c|c|c|c|c|c|c|c|c|c|c|}
\hline \multirow[b]{2}{*}{ Species } & \multicolumn{2}{|c|}{$\begin{array}{|ll|}\text { Cap } & \text { de } \\
\text { Naze } & \\
\end{array}$} & \multicolumn{2}{|c|}{$\begin{array}{l}\text { Diakhanor- } \\
\text { Sangomar }\end{array}$} & \multicolumn{2}{|c|}{$\begin{array}{l}\text { Mbodiène- } \\
\text { Ngazobil }\end{array}$} & \multicolumn{2}{|c|}{$\begin{array}{l}\text { Yenne- } \\
\text { Bargny }\end{array}$} & \multicolumn{2}{|c|}{$\begin{array}{l}\text { Kafountine } \\
\text {-Cap }\end{array}$} & \multicolumn{2}{|c|}{$\begin{array}{l}\text { Soumbédioune } \\
\text {-Ouakam }\end{array}$} & \multicolumn{2}{|c|}{$\begin{array}{l}\text { Port-baie } \\
\text { de Hann }\end{array}$} & \multicolumn{2}{|l|}{ Total } \\
\hline & $\begin{array}{l}\mathrm{Nb} \\
\text { ind. }\end{array}$ & $\%$ & $\begin{array}{l}\mathrm{Nb} \\
\text { ind. }\end{array}$ & $\%$ & $\begin{array}{l}\mathrm{Nb} \\
\text { ind. }\end{array}$ & $\%$ & $\begin{array}{l}\mathrm{Nb} \\
\text { ind. }\end{array}$ & $\%$ & $\begin{array}{l}\mathrm{Nb} \\
\text { ind. }\end{array}$ & $\%$ & $\mathrm{Nb}$ ind. & $\%$ & $\begin{array}{l}\mathrm{Nb} \\
\text { ind. }\end{array}$ & $\%$ & $\begin{array}{l}\text { Total } \\
\text { ind. }\end{array}$ & $\%$ \\
\hline Caranx rhonchus & 1 & 0.04 & 733 & 29.7 & 1595 & 64.6 & 22 & 0.89 & - & - & 76 & 3.1 & 43 & 1.74 & 2470 & 38.65 \\
\hline $\begin{array}{l}\text { Engraulis } \\
\text { encrasicolus }\end{array}$ & - & - & 5 & 1.5 & 326 & 97.9 & - & - & - & - & - & - & 2 & 0.6 & 333 & 5.20 \\
\hline Ethmalosa fimbriata & 9 & 0.5 & 687 & 38.4 & 648 & 36.2 & - & - & 398 & 22.3 & - & - & 46 & 2.6 & 1788 & 27.91 \\
\hline Sardinella aurita & 2 & 0.4 & 44 & 8.06 & 379 & 69.4 & 3 & 0.55 & 98 & 18 & - & - & 20 & 3.66 & 546 & 8.52 \\
\hline $\begin{array}{l}\text { Sardinella } \\
\text { maderensis }\end{array}$ & 9 & 0.8 & 207 & 18.6 & 359 & 32.3 & 176 & 15.8 & 160 & 14.4 & 46 & 4.1 & 155 & 13.9 & 1112 & 17.36 \\
\hline Scomber colias & - & - & - & - & - & - & - & - & - & - & - & - & 129 & 100 & 129 & 2.01 \\
\hline Trachurus trecae & - & - & - & - & - & - & - & - & - & - & - & - & 28 & 100 & 28 & 0.44 \\
\hline Sardina pilchardus & - & - & - & - & - & - & - & - & - & - & - & - & 1 & 100 & 1 & 0.02 \\
\hline Total & 21 & - & 1676 & - & 3307 & - & 201 & - & 656 & - & 122 & - & 424 & - & 6407 & 100 \\
\hline$\%$ & 0.3 & - & 26.2 & - & 51.6 & - & 3.1 & - & 10.2 & - & 1.9 & - & 6.6 & - & 100 & - \\
\hline
\end{tabular}

$\mathrm{Nb}$. ind: Number of individuals.

Table 2. Proportion of catches (\%) of target species by site

\begin{tabular}{l|c|c|c}
\hline \multirow{2}{*}{ Sites } & $\begin{array}{c}\text { Total catch for all } \\
\text { Species }\end{array}$ & $\begin{array}{c}\text { Total catch for } \\
\text { targeted Species }\end{array}$ & $\begin{array}{l}\text { Proportions } \\
\text { targeted Species (\%) }\end{array}$ \\
\cline { 2 - 4 } & $(\mathrm{kg})$ & 3.3 & $0.47 \%$ \\
\hline Cap de Naze & 703.5 & 235.1 & $54.17 \%$ \\
\hline Diakhanor-Sangomar & 434 & 728.5 & $13.63 \%$ \\
\hline Mbodiène-Ngazobil & 5343.2 & 1.1 & $0.92 \%$ \\
\hline Yenne-Bargny & 119.6 & 27.1 & $22.66 \%$ \\
\hline Soumbédioune-Ouakam & 119.6 & 31.4 & $5.54 \%$ \\
\hline Kafountin-Cap & 567 & 112.8 & $33.08 \%$ \\
\hline Port-Baie de Hann & 341 & 1139.3 & $14.94 \%$ \\
\hline
\end{tabular}

\subsubsection{Size Spectrum}

With the exception of the Port-Baie de Hann site, where adult of Caranx rhonchus were observed, juveniles $\left(<\mathrm{L}_{50}\right)$ of the same species were found in the other sites. In Bargny-Yenne, the modal size (TM), which was $15 \mathrm{~cm}$, was represented by $75 \%$ of 


\section{Macrothink}

individuals. In the Mbodiène-Ngazobil site, a modal size of $9 \mathrm{~cm}$, represented by $85 \%$ of individuals, was noted. Two modal sizes, one of $7 \mathrm{~cm}(18 \%)$ and the other of $15 \mathrm{~cm}(50 \%)$ characterized the species in the Soumbédioune-Ouakam site (Figure 2A).

About Ethmalosa fimbriata, adults predominated (60\% in Diakhanor-Sangomar and $38 \%$ in Kafountine-Cap). However, in the Cap de Naze and Mbodiène-Ngazobil sites, in addition to adults (30\% and $40 \%$ respectively), the occurrence of juveniles was high (25 and 10\% respectively) (Figure 2B).

For Sardinella maderensis, a presence of only juveniles was noted in the Soumbédioune-Ouakam site with a modal size of $9 \mathrm{~cm}(55 \%)$. In contrast, in the Bargny-Yenne site, only adults were observed, with a modal size of $25 \mathrm{~cm}(70 \%)$. At the Kafountine-Cap and Diakhanor-Sangomar sites, both juveniles and adults were observed. However, high dominance of juveniles (TM: $15 \mathrm{~cm}$ (70\%)) and adults (TM: $20 \mathrm{~cm}$ (35\%)) of $S$. maderensis were noted in these sites, respectively. As for the Mbodiène-Sangomar site, it was characterized by an important presence of both juveniles and adults of the species with modal sizes of $15 \mathrm{~cm}(30 \%)$ and $23 \mathrm{~cm}$ (20\%), respectively (Figure 2C).

For $S$. aurita, only juveniles were found in the Kafountine-Cap site (TM: $13 \mathrm{~cm}(65 \%)$ ). In contrast, in the Mbodiène-Ngazobil site, both juveniles and adults were observed (Figure 2D). As for Engraulis encrasicolus, although the presence of some adults was noted, most of the individuals caught were juveniles (TM: $8 \mathrm{~cm}(70 \%)$ ). In the Port-Baie de Hann site, all individuals of Scomber colias and Trachurus trecae had sizes larger than their $\mathrm{L}_{50}$ (Figure 2D). 

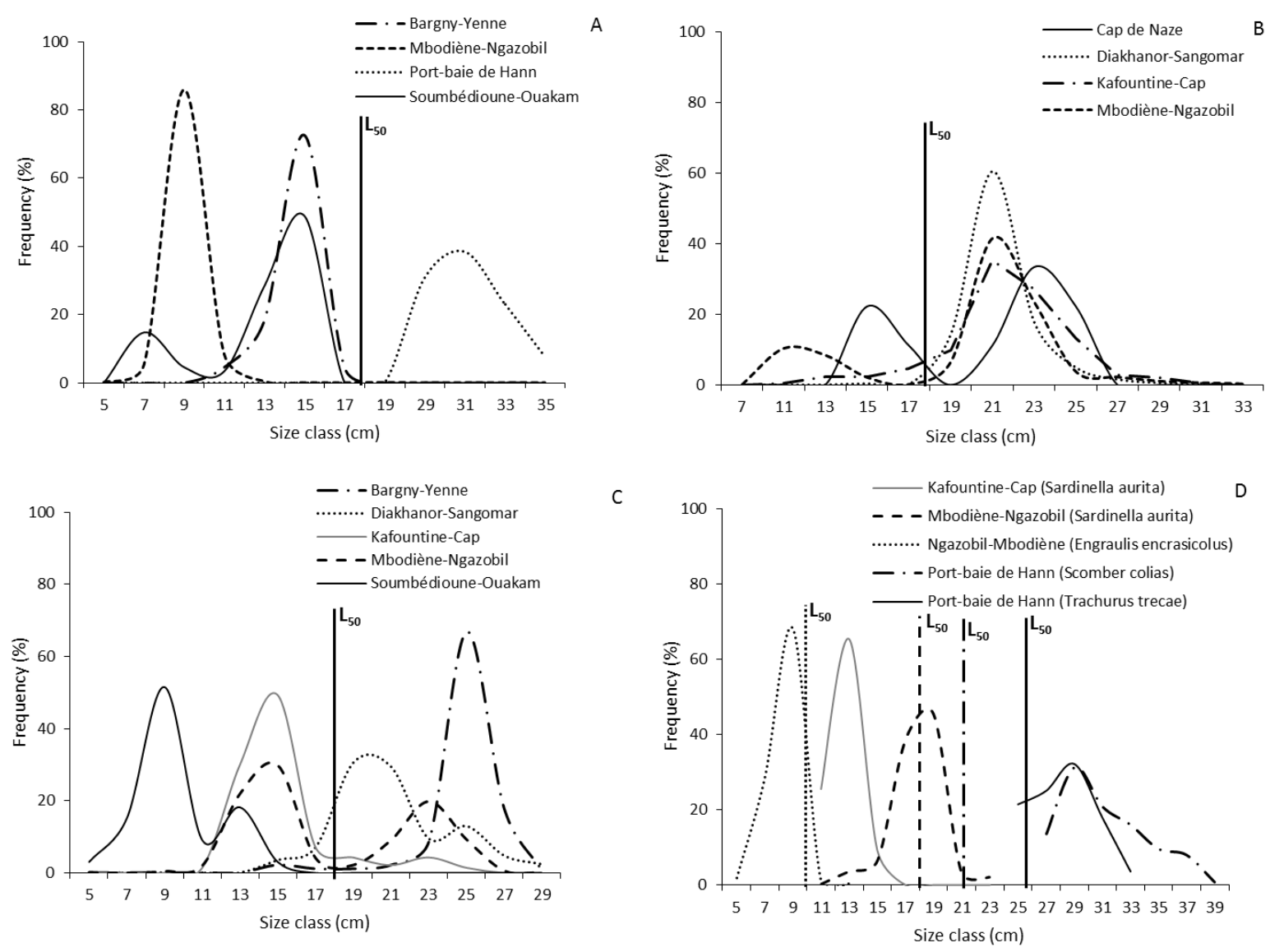

Figure 2. Size frequency distribution of target species: A) Caranx rhonchus, B) Ethmalosa fimbriata, C) Sardinella maderensis, D) Engraulis encrasicolus, Sardinella aurita, Scomber colias, and Trachurus trecae according the sites. $\mathrm{L}_{50}$ : size of first sexual maturity. In figure 2D: dotted line ( $\mathrm{L}_{50}$ for E. encrasicolus), full line ( $\mathrm{L}_{50}$ for Trachurus tracae), line with dash $\left(\mathrm{L}_{50}\right.$ for Sardinella aurita), and dotted line with dash $\left(\mathrm{L}_{50}\right.$ for Scomber colias)

\subsubsection{Sexual Maturity Stages}

With the exception of the Port-Baie de Hann site where adults (stage $\geq 3$ ) at the spawning and post-laying stage were observed, immatures (stage $<3$ ) of $C$. rhonchus were encountered in the others sites where the species was captured (Figure $3 \mathrm{~A}$ ).

For E. fimbriata, at the sites where the species was encountered, significant proportions (57\% at Cape de Naze) of adults from stages 3 to 6 were observed. Immatures were also captured at these sites, but at relatively low proportions (30\% Mbodiene-Ngazobil) compared to adults (Figure 3B).

Immatures of S. maderensis were found in all sites in very large proportions $(98 \%$ in Soumbédioune-Ouakam). In addition, mature adults (stages 3 to 5) were captured at the Kafountine-Cap, Mbodiène-Ngazobil, and Diakhanor-Sangomar sites (Figure 3C).

The individuals of S. aurita and E. encrasicolus captured in the Mbodiène-Ngazobil site were 


\section{Macrothink}

sexually undifferentiated (89\%) and of stage $3(70 \%)$, respectively. The species Scomber colias and Trachurus trecae captured only in the Port-Baie de Hann site were represented by mature individuals (stages 3 to 6), (Figure 3D).
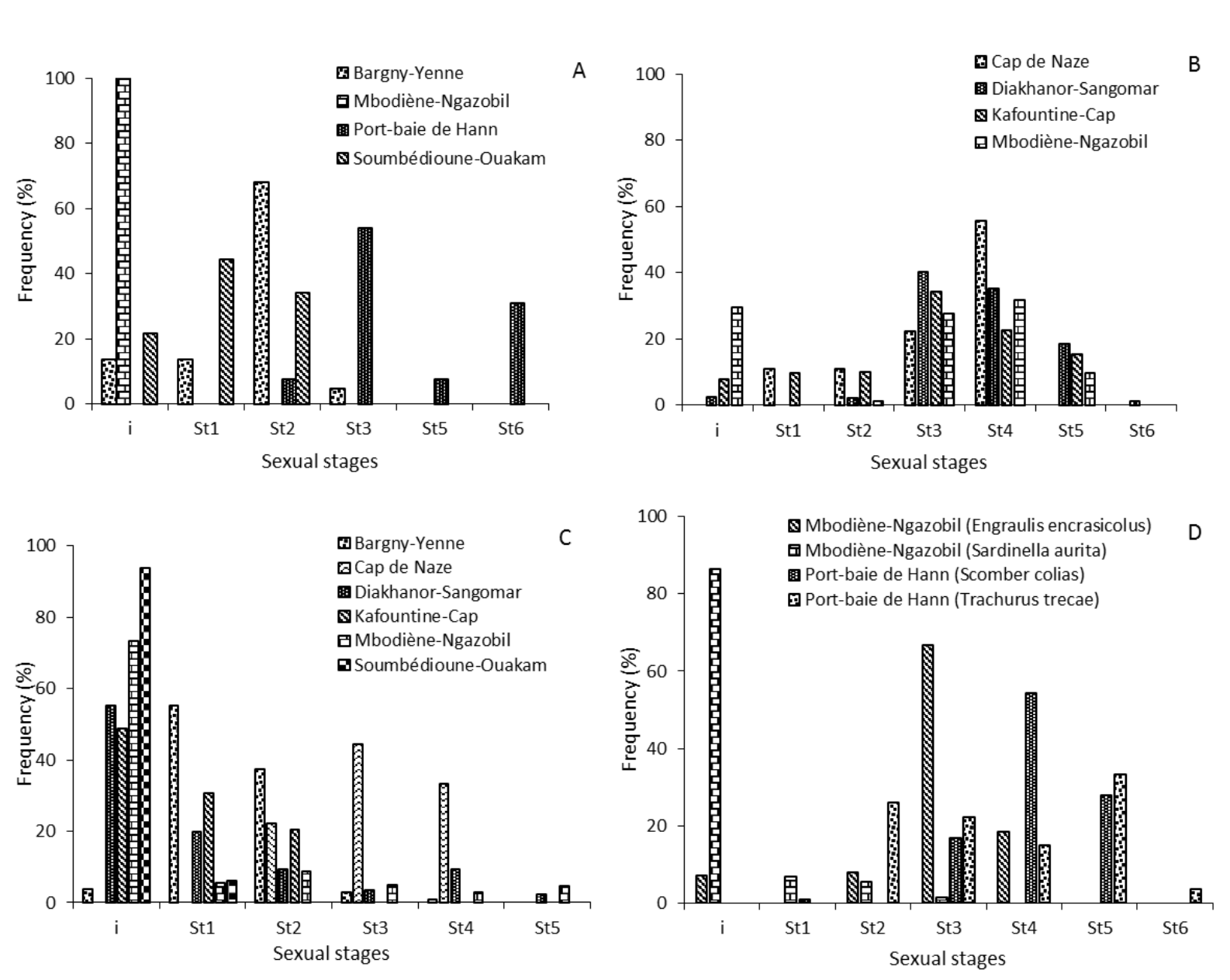

Figure 3. Sexual maturity stages of target species: A) Caranx rhonchus, B) Ethmalosa fimbriata, C) Sardinella maderensis, D) Engraulis encrasicolus, Sardinella aurita, Scomber colias, and Trachurus trecae according the sites

\subsubsection{Condition Factor (K)}

The highest $\mathrm{K}$ values were recorded at the Cap de Naze, Mbodiène-Ngazobil and Diakhanor-Sangomar sites (1.05 to 1.14). In contrast, the lowest $\mathrm{K}$ values were noted in the sites of Port-Baie de Hann and Soumbédioune-Ouakam (0.89). Intermediate values were noted in the Yenne-Bargny and Kafountine-Cap sites (0.73 to 0.87). However, for these last two sites, high $\mathrm{K}$ values were noted respectively for $C$. rhonchus $(0.88)$ and $E$. fimbriata (0.89), (Figure 4). 


\section{$\triangle$ Macrothink}

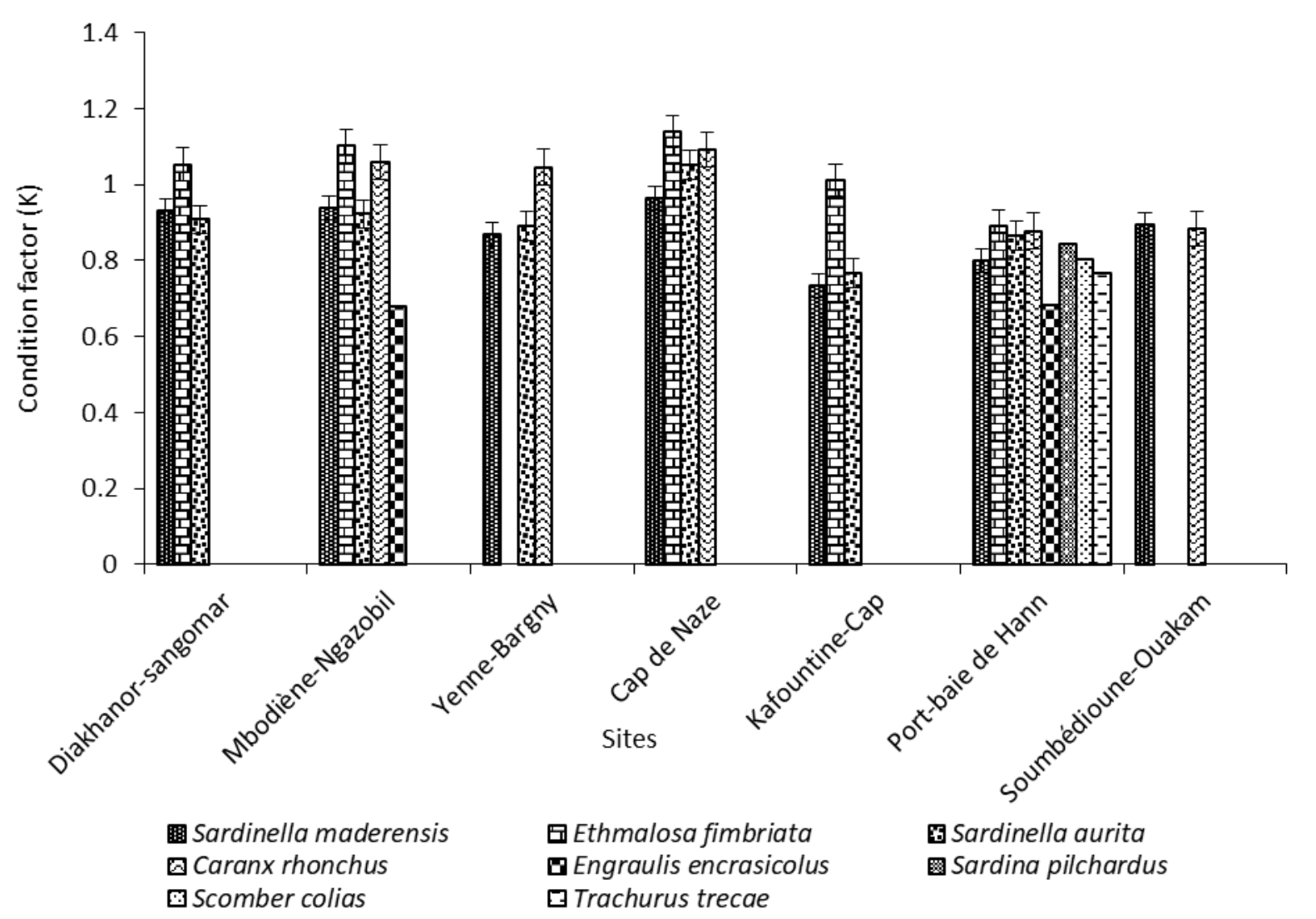

Figure 4. Evolution of the condition factor for target species according to sites along the south marine coastal area of Senegal

\subsubsection{Multivariate Analysis}

The Hierarchical Classification Analysis (HCA) method allowed to classify sites in four groups relative to their species abundance (Figure 5A). A projection of these groups was done using the Factorial Correspondence Analysis (FCA). The FCA, carried out on the species abundance (Figure 5B), showed that the 1-2 factorial plane explained $81.7 \%$ of the total inertia (45.5\% for axis 1 and $36.2 \%$ for axis 2). Therefore, results obtained from the first two axes were plotted. The factorial plan 1-2 showed that these groups were clearly distinct (Figure 5B). The first group corresponding to the Mbodiène-Ngazobil site presented a high abundance for the species S. aurita and E. encrasicolus (corresponding to $74.9 \%$ and $99.4 \%$, respectively). The second group representing the Port-Baie de Hann site was characterized by high abundance for $T$. trecae and $S$. colias (100\% of the sites, both). The Diakhanor-Sangomar, where the highest abundance of E. fimbriata (43.4\%) was noted, represented the third group. The fourth group was marked by high abundances of $S$. maderensis, $C$. rhonchus, and $S$. aurita depending on sites. This group included the sites of Cap de Naze, Soumbédioune Ouakam, Kafountine Cap, and Bargny-Yenne. 

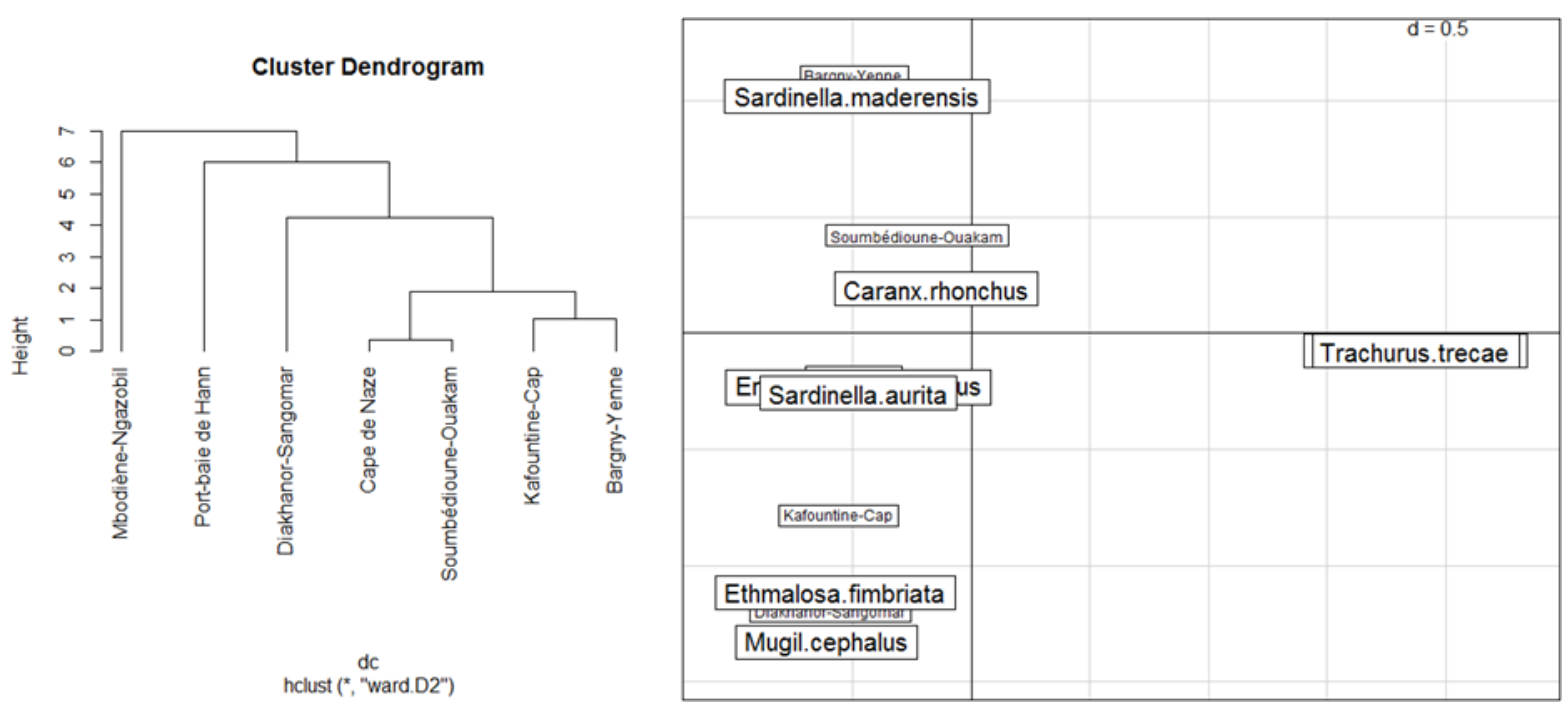

Figure 5. erarchical Classification Analysis (HCA) performed using species abundance from the different critical sites and Factorial Correspondence Analysis (FCA) relating associations of critical sites to species abundance

\section{Discussion}

Lebous, guet-ndariens and niominkas are the main traditional fishing communities in Senegal holding empirical knowledge of fishing activity and the dynamics of fisheries resources. As for the natives, they are the ones who have better control over the realities of the evolution of the fishery resources in their localities. The predominance of fishermen with experience between 20 and 30 years in the survey justifies the importance of fishing experience and especially the identification of critical sites for small pelagics. The predominance of specialized fishermen in pelagic fisheries or in the use of mixed fishing gear was also an asset in the validity of the information provided by fishermen in view of their knowledge of the target species.

\subsection{Nursery and Spawning Ground}

\subsubsection{Size Spectrum}

The analysis of the size spectrum of small pelagic species provided a clear overview of the bio-ecological characteristics of the sites identified along Senegal's coastal zone. The Mbodiène-Ngazobil, Port-Bay of Hann, Kafountine-Abéné and Yenne-Bargny sites were characterized by high concentrations of both juveniles and potential small pelagic spawners. These results are consistent with previous observations, which showed that small individuals are encountered in the southern zone from July to December (Freon, 1988; Brochier et al., 2018).

In addition, the sites of Mbodiène-Ngazobil and Port-Baie de Hann had a high target species diversity (S. aurita, S. maderensis, Engraulis encrasicolus, Ethmalosa fimbriata and Caranx rhonchus), for the vulnerable stages. T. trecae and Scomber colias were exclusively found in the site of Port-bay of Hann. Kafountine-Abéné represented a nursery for both Sardinella and a concentration site for spawners of Ethmalosa. For the Yenne-Bargny site, juveniles of 
Caranx rhonchus and both juveniles and adults of Sardinella maderensis were observed. The site of Diakhanor-Sangomar was marked by the presence of high concentrations of mature adults of S. maderensis and E. fimbriata. In contast, that of Soumbédioune-Ouakam was mainly home to concentrations of juveniles of $C$. rhonchus and $S$. maderensis.

These results are a refinement of earlier works conducted along the Senegalese continental shelf. Those works had identified the Petite Côte area (southern Cape Verde) and Casamance as nursery areas (Tiedemann and Brehmer, 2017; Brochier et al., 2018), and also an eggs and larvae retention area for small pelagics (Mbaye et al., 2015; Ndour et al., 2018). The effect of topographic features, such as capes and headlands modulates dramatically the onshore movement of upwelled water and favors the formation of stationary coastal upwelling centers (Faye et al., 2015; Capet et al., 2017). The retention of near-shore surface waters plays a major ecological role in the breeding of small pelagic fish (Ndoye et al., 2018).

\subsubsection{Sexual Maturity Stages}

The encountered sexual stages of the targeted species explained that the sites, where they were found, were nurseries and spawning grounds for small pelagics. However, there was a trend to spawning or nursery according to the sites, and a specificity of certain sites to some species. In fact, the Port-Baie de Hann and Mbodiène-Ngazobil sites were nursery and spawning sites that had the highest biological diversity in terms of target species. In addition, the Port-Baie de Hann site was characterized by the presence of species such as T. trecae and $S$. colias that had not been found in the other sites. In addition to these sites, there was Kafountine-Abéné, which was both a spawning site for ethmalose and nursery for both Sardinella species. The sites of Cap de Naze, Yenne Bargny and Soumbédioune-Ouakam had a strong trend for the nursery and that for a certain number of species according to the site $(C$. rhonchus, S. aurita, S. maderensis, and E. fimbriata). The Diakhanor-Sangomar site had a strong spawning trend for the species $S$. aurita, E. fimbrata and $S$. maderensis. Like the work of Ba et al. (2019), our results did not show a clear link between marine protected areas and critical sites for small pelagics identified in the study. The main common characteristic of the sites described was that they were generally located outside the MPAs and were located most often at the outlet of the mouths of rivers.

These results are consistent with those of Sarré et al. (2018), which showed that areas of high concentrations of adults of Sardinella were located south of Cape Verde and off Casamance. They also confirm the results obtained on the retention zones (Mbaye et al., 2015), of nursery (Brochier et al., 2018), spawning grounds (Tiedemann and Brehmer, 2017), and of high concentration of pelagic fish larvae (Ndour et al., 2018) along the coastal marine area of Senegal.

\subsubsection{Vulnerability of the Sites}

High $\mathrm{K}$ values for most target species at the Cap de Naze, Mbodiène-Ngazobil, and Diakhanor-Sangomar sites could be explained by the advection of upwelled waters arriving in these areas (Capet et al., 2017; Ndoye et al., 2018). To this, could also be added the quality and availability of food in the Petite Côte, an area recognized as one of the richest in primary 
and secondary production (Diadhiou et al., 2017; Ndour et al., 2018), and very favorable to small pelagics (Diankha et al., 2018). The low values of K noted in the sites of Port-Baie de Hann and Soumbedioune-Ouakam could be the result of an environment unfavorable to the target species under the effect of marine pollution in the coastal area of Dakar, and Hann Bay in particular (Bouvy et al., 2008; Net et al., 2015; Diop and Amara, 2016).

The clustering of sites, based on multivariate analyzes, demonstrates their different characteristics in terms of relative abundance and species diversity. The irregularity of the continental shelf structure along the southern coastal zone, which could affect environmental conditions, could explain the observed situation. Ba et al. (2016) showed that Sardinella are not very sensitive to long-term climatic fluctuations. However, the work of Diankha et al. (2018) have shown that the variability of Sardinella recruitment is related to fluctuations in surface temperature. These results are also consistent with those of Baldé et al. (2018), which explain the variability of recruitment in Ethmalosa fimbriata, by the effect of local climate variability.

In addition to the bioecological characteristics, there were threats that increase the vulnerability of the sites. According to the fishermen, the main threat identified in the Mbodiène-Ngazobil site was the high fishing pressure and especially the large number of beach seines in the area. As for the Diakhanor-Sangomar site, besides the threat of high fishing pressure (including fishing boats), exploration of oil off Sangomar could be a risk factor. For the Yenne-Bargny site, it was threatened by the installation of illegal sites for juveniles of small pelagics processing, which increased the fishing pressure on the resource. In addition, marine pollution affects fish habitats. A potential threat that could be related to oil exploration off Rufisque was also identified by the fishermen. The sites of Port-Baie de Hann and Soumbedioune-Ouakam were threatened by a very marked coastal marine pollution. The ongoing construction of the port of Ndayanne (Petite Côte) was a significant potential threat to the Cap de Naze site according to fishermen. Regarding the Kafountine-Abéné site, it was affected by high fishing pressure, because of the transfer of the fishing effort to the south part due to the scarcity of the resource north part of Senegal.

\section{Conclusion}

This study provides a better understanding of the structuring of sites of bioecological interest for small pelagic species along the coastal marine zone of Senegal. This result was obtained through the identification and characterization of sites of bio-ecological interest within the framework of the new management concept of small pelagic resources called "critical site", developed by the Sub-Regional Fisheries Commission (SRFC). This work is a flagship contribution to the improvement of the management of small pelagic resources, which until now has been the weak link in the sub-regional sustainable management system for small pelagics. 


\section{References}

Albaret, J. J., \& Legendre, M. (1985). Biologie et écologie des Mugilidae en lagune Ebrié (Côte d'Ivoire). Intérêt potentiel pour l'aquaculture. Revue d'Hydrobiologie, 18(4), 281-303.

Ba, A., Chaboud, C., Schmidt, J., Diouf, M., Fall, M., Dème, M., \& Brehmer, P. (2019). The potential impact of marine protected areas on the Senegalese Sardinella fishery. Ocean and Coastal Management, 169, 239-246. https://doi.org/10.1016/j.ocecoaman.2018.12.020

Ba, A., Schmidt, J., Dème, M., Lancker, K., Chaboud, C., Cury, P., Thiao, D., Diouf, M., \& Brehmer, P. (2017). Profitability and economic drivers of small pelagic fisheries in West Africa: A twenty year perspective. Marine Policy, 76, 152-158.

https://doi.org/10.1016/j.marpol.2016.11.008.

Ba, K., Thiaw, M., Lazar, N., Sarr, A., Brochier, T., Ndiaye, I., Faye, A., ... Brehmer, P. (2016). Resilience of key biological parameters of the senegalese flat Sardinella to overfishing and climate change. PLoS ONE, 11(6), e0156143.

https://doi.org/10.1371/journal.pone.0156143

Baldé, B. S., Brehmer, P., Sow, F. N., Ekau, W., Kantoussan, J., Fall, M., \& Diouf, M. (2018). Population dynamics and stock assessment of Ethmalosa fimbriata in Senegal call for fishing regulation measures. Regional Studies in Marine Science, 24, 165-173.

https://doi.org/10.1016/j.rsma.2018.08.003

Bouvy, M., Briand, E., Boup, M. M., Got, P., Leboulanger, C., Bettarel, Y., \& Arfi, R. (2008). Corrigendum to: Effects of sewage discharges on microbial components in tropical coastal waters (Senegal, West Africa). Marine and Freshwater Research, 59(9), 838-839. https://doi.org/10.1071/MF07244_CO

Brochier, T., Auger, P. A., Pecquerie, L., Machu, E., Capet, X., Thiaw, M., ... Brehmer, P. (2018). Complex small pelagic fish population patterns arising from individual behavioral responses to their environment. Progress in oceanography, 164, 12-27.

https://doi.org/10.1016/j.pocean.2018.03.011

Capet, X., Estrade, P., Machu, E., Ndoye, S., Grelet, J., Lazar, A., ... Brehmer, P. (2017). On the dynamics of the southern senegal upwelling center: Observed variability from synoptic to superinertial scales. Journal of Physical Oceanography, 47(1), 155-180. https://doi.org/10.1175/JPO-D-15-0247.1

Cury, P., Bakun, A., Crawford, R. J. M., Jarre, A., Quiñones, R. A., Shannon, L. J., \& Verheye, H. M. (2000). Small pelagics in upwelling systems: patterns of interaction and structural changes in "wasp-waist" ecosystems. ICES Journal of Marine Science, 57(3), 603-618. https://doi.org/10.1006/jmsc.2000.0712

Dème, M. (2012). Étude des connaissances socio-économiques des pêcheries de petits pélagiques au Sénégal. Rapport technique Projet Petits Pélagiques/CSRP, 31p.

Dème-Gning, I., Roy, C., \& Touré, D. (1990). Variabilité spatio-temporelle de la température, des nitrates et de la chlorophylle devant les côtes du Sénégal. Documentation scientifique, Centre de Recherches Océanographique de Dakar-Thiaroye, 122, 21 p.

Diadhiou, H. D., Tine, M., Diallo, A., \& Sylla, M. (2017). A Survey of the Benthic Microfauna of the Marine Ecosystem on IRIS-1 Oil Platform at the Cape Skiring in Casamance, Senegal. Fisheries and Aquaculture Journal, 8, 234. 
https://doi.org/10.4172/2150-3508.1000234

Diankha, O., Ba, A., Brehmer, P., Brochier, T., Sow, B. A., Thiaw, T., ... Demarcq, H. (2018). Contrasted optimal environmental windows for both Sardinella species in Senegalese waters. Fisheries Oceanography, 00, 1-15. https://doi.org/10.1111/fog.12257

Diop, M., \& Amara, R. (2016). Mercury concentrations in the coastal marine food web along the Senegalese coast. Environmental Science and Pollution Research, 23(12), 11975-11984. https://doi.org/10.1007/s11356-016-6386-x

Faye, F., Lazar, A., Sow, B. A., \& Gaye, A. T. (2015). A model study of the seasonality of sea surface temperature and circulation in the Atlantic Northeastern Tropical Upwelling System. Frontiers of Physics, 3, 76. https://doi.org/10.3389/fphy.2015.00076

Fréon, P. (1988). Réponses adaptatives des stocks de clupéidés d'Afrique de l'Ouest à la variabilité du milieu et de l'exploitation. Analyse et réflexion à partir de l'exemple du Sénégal. Editions de l'ORSTOM, Collection Etudes et Thèses, Paris, 287 p.

Mbaye, A. (2018). Pêche artisanale sénégalaise et gouvernance du changement climatique, Thèse de doctorat unique, Muséum National, d'Histoire Naturelle, Ecole Doctorale Sciences de la Nature et de l'Homme - ED 227, Paris, 336p.

Mbaye, B. C., Brochier, T., Echevin, V., Lazar, A., Lévy, M., Maso, E., ... Macha, E. (2015). Do Sardinella aurita spawning seasons match local retention patterns in the Senegalese-Mauritanien upwelling region? Fisheries Oceanography, 24(1), 63-85P. https://doi.org/10.1111/fog.12094

Ndour, I., Berraho, A., Fall, M., Ettahiri, O., \& Sambe, B. (2018). Composition, distribution and abundance of zooplankton and ichthyoplankton along the Senegal-Guinea maritime zone (West Africa). Egyptian journal of aquatic research, 44, 109-124. https://doi.org/10.1016/j.ejar.2018.04.001

Ndoye, S., Capet, X., Estrade, P., Machu, E., Kounta, L., Sow, B., ... Gaye, A. T., (2018). A numerical modeling study of the Southern Senegal upwelling shelf: Circulation and upwelling source waters. African Journal of Environmental Science and Technology, 12(12), 487-500. https://doi.org/10.5897/AJEST2018.2572

Net, S., Henry, F., Rabodonirina, S., Diop, M., Merhaby, D., Mahfouz, C., ... Ouddane, B. (2015). Accumulation of PAHs, Me-PAHs, PCBs and total Mercury in sediments and Marine Species in Coastal Areas of Dakar, Senegal: Contamination level and impact. International Journal of Environmental Research, 9(2), 419-432.

Ricker, W. E. (1975). Computation and interpretation of biological statistics of fish populations. Bulletin of the Fisheries Research Board of Canada, 191, 1-382.

Roy, C. (1989). Fluctuations des vents et variabilité de l'upwelling devant les côtes du Sénégal. Oceanologica Acta, 12(4), 361-369.

Sarré, A., Krakstad, J. O., Brehmer, P., \& Mbye, E. M. (2018). Spatial distribution of main clupeid species in relation to acoustic assessment surveys in the continental shelves of Senegal and The Gambia. Aquatic Living Resources, 31, 9.

https://doi.org/10.1051/alr/2017049

Thiaw, M., Auger, P. A., Ngom, F., Brochier, T., Faye, S., Diankha, O., \& Brehmer, P. (2017). Effect of environmental conditions on the seasonal and inter-annual variability of small 


\section{Macrothink}

Journal of Biology and Life Science ISSN 2157-6076 2020, Vol. 11, No. 1

pelagic fish abundance off North-West Africa: The case of both Senegalese Sardinella. Fisheries Oceanography, 26, 583-601. https://doi.org/10.1111/fog.12218

Tiedemann, M., \& Brehmer, P. (2017). Larval fish assemblages across an upwelling front: Indication for active and passive retention. Estuarine, Coastal and Shelf Science, 187, 118-133. https://doi.org/10.1016/j.ecss.2016.12.015

\section{Copyright Disclaimer}

Copyright for this article is retained by the author(s), with first publication rights granted to the journal.

This is an open-access article distributed under the terms and conditions of the Creative Commons Attribution license (http://creativecommons.org/licenses/by/3.0/). 